\title{
EWANGELIZACYJNA MISJA KOŚCIOŁA WYZWANIEM MORALNYM U PROGU TRZECIEGO TYSIĄCLECIA
}

\section{WSTĘP}

Obserwując dokonujące się $\mathrm{w}$ świecie przemiany, łatwo można zauważyć aktualność i potrzebę zaangażowania wszystkich chrześcijan w ewangelizacyjną misję Kościoła. Ojcowie soborowi, jak i wielu papieży w czasie swoich pontyfikatów "walczyło" mocno o odnalezienie i ukazanie misyjności Kościoła. Ich życie i działalność przeniknięte były duchem misji. Ta postawa odbiła się bardzo mocno $\mathrm{w}$ ich nauczaniu. Wielość wypowiedzi soborowych i papieskich pozwala też ukazać różne aspekty ciągłej i naglącej potrzeby ewangelizacji współczesnego świata.

Papież Benedykt XVI w adhortacji apostolskiej Verbum Domini uświadamia, że „u progu trzeciego tysiąclecia nie tylko istnieją liczne ludy, które jeszcze nie poznały Dobrej Nowiny, ale wielu chrześcijan

* Ks. dr Marek Kluz - adiunkt Katedry Teologii Moralnej i Duchowości Wydziału Teologicznego Sekcja w Tarnowie Uniwersytetu Papieskiego Jana Pawła II w Krakowie, sekretarz WTST. Autor kilkudziesięciu artykułów naukowych poświęconych moralności małżeńsko-rodzinnej, wychowania moralnego, bioetyce, moralności życia społecznego i działalności socjalno-charytatywnej. 
potrzebuje, aby na nowo głoszono im z przekonaniem słowo Boże, by mogli konkretnie doświadczyć mocy Ewangelii. Tylu jest braci 'ochrzczonych, ale nie wystarczająco ewangelizowanych'. Często kraje niegdyś bogate w wiarę i powołania tracą swoją tożsamość pod wpływem kultury zeświecczonej. O potrzebie nowej ewangelizacji, [...] o skuteczności słowa Bożego należy mówić na nowo bez lęku, przekonaniem”"1. Misja ewangelizacyjna jest świadectwem wiary, chrześcijańskiej dojrzałości i formacji. Jest również świadectwem odpowiedzialności moralnej za tych, którzy nie poznali jeszcze Chrystusa. Należy więc zadbać o to, by czynienie z siebie daru dla bliźnich, było fundamentalnym powołaniem i przywilejem wszystkich chrześcijan tworzących wspólnotę Kościoła.

Dlatego niniejsze studium ma na celu ukazanie wyzwań moralnych, jakie stoją przed uczniami Chrystusa na progu trzeciego tysiąclecia w dziele misji ewangelizacyjnej Kościoła. Należy pamiętać, że już przez sam fakt przynależności do wspólnoty Kościoła, który z natury jest misyjny, każdy chrześcijan zostaje mniej lub bardziej świadomie włączony w proces ewangelizowania świata (1). I to zadanie powinien wypełniać z wielkim zaangażowaniem. Aby tak było, potrzebna jest odpowiednia formacja misyjna. Dokonuje się ona poprzez sakramenty święte, zwłaszcza chrzest, bierzmowanie i Eucharystię. Są one początkiem drogi przyjęcia odpowiedzialności moralnej za Kościół misyjny (2). Ważnymi dziś aspektami formacji misyjnej - jeśli nie najważniejszymi - są inkulturacja i dialog międzyreligijny (3). Nie są to sprawy łatwe, ale z punktu widzenia moralnego niezwykle istotne, bo odnawiają jedność Kościoła, są drogami, pozwalającymi dotrzeć do umysłów i serc ludzkich. Te problemy moralne dotyczące fundamentalnych aspektów życia misyjnego Kościoła staną się przedmiotem analizy.

\section{MISYJNY WYMIAR ŻYCIA MORALNEGO KOŚCIOŁA}

Papież Benedykt XVI we wspomnianej wyżej adhortacji Verbum Domini wyraźnie stwierdza, że „cały Kościół jako tajemnica komunii jest misyjny i każdy, zgodnie ze swoim stanem życia, jest powołany do tego, by wnieść znaczący wkład w głoszenie chrześcijańskiego orędzia"². Zada-

${ }^{1}$ Benedykt XVI, Adhortacja apostolska Verbum Domini, Rzym 2010, nr 96 (dalej: VD).

2 Tamże, nr 94. 
nie to powierzył Chrystus Apostołom, a tym samym całemu Kościołowi, słowami: „Idźcie na cały świat i głoście Ewangelię wszelkiemu stworzeniu" (Mk 16, 15). Kościół winien zatem być misyjny, by w ten sposób zachowywać swoją tożsamość. W misyjności swojej Kościół odnajduje korzenie i punkt wyjścia. Misyjność ta narzuca również Kościołowi jego charakter. Charakter bowiem jest to piętno, cecha wyróżniająca danej rzeczy lub osoby ${ }^{3}$. Kościół wyrasta, rodzi się ze swojej misyjności, wyrasta z ewangelizacji, którą sprawował sam Chrystus. Jest ukształtowany tą misyjnością i na niej wciąż się opiera ${ }^{4}$.

Posłanie Kościoła do głoszenia Dobrej Nowiny było kontynuacją posłania Jezusa. Po wypełnieniu misji, którą zlecił Mu Ojciec Niebieski Jezus mówi do Apostołów: "Jak Ojciec Mnie posłał, tak i Ja was posyłam” (J 20, 21). Podkreślając ciągłość, jaka zaistniała pomiędzy Ojcem, Synem i Jego uczniami, Jezus mówi do Ojca: „Jak Ty Mnie posłałeś na świat, tak i Ja ich na świat posłałem” (J 17, 18). "Sami bowiem Apostołowie, na których Kościół został założony, idąc w ślady Chrystusa, «głosili słowo prawdy i rodzili Kościoły». A zadaniem ich następców jest nieustannie prowadzić to dzieło, aby «słowo Pańskie szerzyło się i rozsławiało» (2 Tes 3,1) i aby Królestwo Boże na całym świecie głoszono i zakładano" ${ }^{\prime \prime}$.

Apostołowie rozpoczęli więc swoje przepowiadanie bezpośrednio po otrzymaniu Ducha Świętego w dniu Pięćdziesiątnicy, zwanym często dniem narodzin Kościoła. Nowe życie, wlane przez Ducha, spontanicznie popchnęło ich do przekazywania go innym. Był to zarazem obowiązek, by Kościół w wypełnianiu swego posłannictwa posyłał głosicieli Ewangelii, aby przepowiadali Dobrą Nowinę o zbawieniu. Tak więc i teraz, w dzisiejszych czasach Kościół posyła swoich misjonarzy, jak niegdyś przełożeni Kościoła w Antiochii, po uprzednim poście i modlitwie, nałożyli swe ręce na Barnabę i Pawła i posłali ich jako misjonarzy, jak polecił Duch Święty (por Dz 13, 2-3) .

Jan Paweł II w encyklice Redemptoris missio podkreślił, że Kościół jest pierwszym, który korzysta z dóbr zbawienia7. Wyjaśniają to słowa

${ }^{3}$ Por. W. Kopaliński, Stownik wyrazów obcych i zwrotów obcojęzycznych, Warszawa 1985, s. 73.

4 Por VD 91.

${ }^{5}$ Sobór Watykański II, Dekret o działalności misyjnej Kościoła "Ad gentes divinitus", w: Sobór Watykański II, Konstytucje, Dekrety, Deklaracje, Poznań 1968, nr 1 (dalej: DM).

${ }^{6}$ Por. P. Vadakumpadan, Eklezjologiczne podstawy misji, w: Kościót misyjny, red. S. Karotemprel, Warszawa 1997, s. 90-91.

7 Por. Jan Paweł II, Encyklika „Redemptoris missio, Watykan 1990, nr 9 (dalej: RM). 
Dziejów Apostolskich, które mówią, że Chrystus ów Kościół nabył „własną krwią" (Dz 20, 28). Zachodzi więc między Chrystusem, Kościołem i ewangelizacją jak najściślejszy związek. Kościół posiada powierzony sobie urząd ewangelizowania. I nie godzi się korzystać z tego urzędu bez Kościoła, albo tym bardziej przeciw niemu. Ewangelizacja jest zawsze aktem eklezjalnym ${ }^{8}$. „Nie jest to czyjakolwiek czysto osobista inicjatywa. W porządku łaski i na płaszczyźnie instytucjonalnej każdy ewangelizujący i cała działalność ewangelizacyjna są związane z Kościołem powszechnym. Nie ma takiej działalności ewangelizacyjnej, która byłaby misją paralelną do misji Kościoła lub, co więcej, przeciwna Kościołowi" ${ }^{\prime 9}$.

Chrystus pragnął, aby Kościół był sakramentem zbawienia dla wszystkich ludzi na ziemi. „Powszechność zbawienia nie oznacza, że otrzymują je tylko ci, którzy w wyraźny sposób wierzą w Chrystusa i weszli do Kościoła. Jeśli zbawienie zostało przeznaczone dla wszystkich, musi ono być dane konkretnie do dyspozycji wszystkich"10. Kościół nie istnieje dla siebie samego, lecz dla prowadzenia ludzi do Jezusa Chrystusa. Nie może zatem zamykać się tylko na działania wewnętrzne. Jego wszelki wysiłek jest ukierunkowany na przepowiadanie i uobecnianie tajemnicy Jezusa Chrystusa. To z kolei wymaga otwarcia i zrozumienia, które pomagają Kościołowi w stawaniu się możliwie najdoskonalszym znakiem zbawienia pośród narodów. Zbawienie, które jest zawsze darem Ducha, pomimo swej dostępności, wymaga jednak współpracy człowieka. Tak zechciał Bóg i dlatego ustanowił Kościół i włączył go w plan zbawienia. Nieustanna modlitwa Kościoła: „przyjdź Królestwo Twoje”, zawiera w sobie jego cel oraz zadanie misji - budowanie Królestwa już tu, na ziemi ${ }^{11}$.

Kościół może zachować swą tożsamość tylko w kontekście swojej misyjności. „Wierność posłannictwu uzdalnia wspólnotę do wzrostu jako Kościół Chrystusowy" ${ }^{\prime \prime 2}$. Ewangelizacja jest pierwszorzędnym powołaniem i znakiem tożsamości Kościoła. Jest największym i najbardziej porywającym wyzwaniem moralnym, wobec którego Kościół staje od początku swego istnienia ${ }^{13}$. Poza tą misją nie ma on celu sam w sobie. Wspólnota (dalej: EN).

${ }^{8}$ Por. Paweł VI, Adhortacja apostolska „Evangelii nuntiandi”, Watykan 1975, nr 60

${ }^{9}$ P. Vadakumpadan, dz. cyt., s. 91.

${ }^{10}$ RM 10.

${ }^{11}$ Por. tamże, nr 9.

${ }^{12}$ P. Vadakumpadan, dz. cyt., s. 86.

${ }^{13}$ Por. Jan Paweł II, Encyklika „Veritatis splendor, Watykan 1993, nr 106 (dalej: VS). 
chrześcijańska ukazuje swoją własną tożsamość w sposób najbardziej widzialny, kiedy jest zgromadzona wokół stołu eucharystycznego. Tu umacnia się koinonia (braterstwo) i Kościół postępuje naprzód w głoszeniu Ewangelii z coraz większym oddaniem. Wspólnota, która celebruje Eucharystię, sama czuje się posłana. Aspekt wzajemnego dawania i otrzymywania jest tu wzmocniony. Eucharystia nieustannie buduje wspólnotę; ona to podsyca tę miłość, która jest duszą wszelkiej ewangelizacji ${ }^{14}$.

W ciągu wieków Kościół wiernie głosił Ewangelię i świadczył o niej ${ }^{15}$. Sam Jezus nie tylko dawał świadectwo prawdzie, lecz był Prawdą. Wspólnota chrześcijańska nie będzie skutecznie przekazywała prawdy przez samo jej posiadanie lub głoszenie, lecz musi żyć prawdą i odnaleźć w niej swą tożsamość. W Kościele za pierwszy środek ewangelizowania należy uważać świadectwo życia prawdziwie chrześcijańskiego, które trwa w nierozłącznej wspólnocie z Bogiem, a zarazem w ożywieniu ducha otwartości i miłości poświęcania się dla innych ${ }^{16}$.

Dzieło zakładania Kościoła w określonej społeczności wtedy osiąga swój pewny kres, gdy zgromadzenie wiernych, zakorzenione już w życiu społecznym i w jakiejś mierze dostosowane do kultury miejscowej, cieszy się pewną trwałością i siłą, tzn. posiada własną, chociaż jeszcze niedostateczną liczbę rodzimych kapłanów, osób zakonnych i świeckich oraz wyposażone jest $\mathrm{w}$ urzędy $\mathrm{i}$ instytucje, które niezbędne są do prowadzenia i rozwoju życia Ludu Bożego pod kierownictwem własnego biskupa. Kiedy młody Kościół, dzięki działalności misyjnej, zaczyna istnieć $\mathrm{w}$ określonym miejscu lub narodzie, wówczas jest on realizowaniem, aczkolwiek ograniczonym, Bożego planu względem wszystkich ludzi z danego miejsca. Ukazuje on tę komunię i nią żyje, jak chciał Ojciec i jak przywrócił ją Chrystus Odkupiciel: „Nie ma już Żyda ani poganina, nie ma już niewolnika ani człowieka wolnego, nie ma już mężczyzny ani kobiety, wszyscy bowiem jesteście kimś jednym w Chrystusie Jezusie" $(\mathrm{Ga} 3,28)^{\prime \prime 17}$.

Misyjny charakter jest więc piętnem, które Kościół nosi od swoich początków. „Powszechna misja Kościoła rodzi się z nakazu Jezusa Chrystusa i urzeczywistnia w ciągu wieków przez głoszenie tajemnicy

\footnotetext{
${ }^{14}$ Por. P. Vadakumpadan, dz. cyt., s. 96.

${ }^{15}$ Kongregacja Nauki i Wiary, Deklaracja o jedyności i powszechności zbawczej Jezusa Chrystusa i Kościoła "Dominus Iesus”, Watykan 2000, nr 2 (dalej: DI).

${ }^{16}$ Por. VS 107; DM 6.

${ }^{17}$ Por. P. Vadakumpadan, dz. cyt., s. 93.
} 
Boga Ojca, Syna i Ducha Świętego oraz tajemnicy wcielenia Syna jako wydarzenia niosącego zbawienie całej ludzkości"18. Uformowana przez Chrystusa wspólnota jest znakiem zjednoczenia, której oczekiwał Ojciec. Zjednoczenie to przywrócone zostało przez Syna w Duchu Świętym. W ostatecznym Słowie swego Objawienia - w swoim Synu Jezusie Chrystusie, Bóg dał się poznać w sposób najpełniejszy: powiedział ludzkości, kim jest. To ostateczne samoobjawienie się Boga jest podstawowym powodem, dla którego Kościół „jest misyjny ze swej natury”. Kościół nie może on nie głosić Ewangelii, gdyż jest ona pełnią prawdy, jaką Bóg dał nam poznać o samym sobie ${ }^{19}$. Misja Chrystusa Odkupiciela, powierzona Kościołowi, nie została jeszcze bynajmniej wypełniona do końca. Gdy na początku trzeciego tysiąclecia od Jego przyjścia obejmujemy spojrzeniem ludzkość, przekonujemy się, że misja Kościoła dopiero się rozpoczyna i że w jej służbie musimy zaangażować wszystkie nasze siły. Nie sposób bowiem oddzielić płaszczyzny życia Kościoła od ewangelizacji ${ }^{20}$.

We współczesnym świecie zadaniem Kościoła jest wcielanie w czyn posłannictwa samego Chrystusa ${ }^{21}$. Głoszenie Ewangelii jest propozycją nowego życia, która nie narusza wolności człowieka. W orędziu ewangelicznym Kościół daje siłę, która wyzwala i tworzy postęp właśnie dlatego, że prowadzi do nawrócenia serca i umysłu, do uznania godności każdej osoby, usposabia do solidarności, zaangażowania w posługę braciom, włącza człowieka w Boży plan, którym jest budowanie Królestwa pokoju i sprawiedliwości już w tym życiu² ${ }^{22}$.

\section{MORALNO-SAKRAMENTALNA FORMACJA CHRZEŚCIJAN DO EWANGELIZACYJNEJ MISJI KOŚCIOŁA}

Niezwykle ważnym zadaniem moralnym jest wgłębienie się w tajemnicę misyjnej formacji, wychowania do misji. Trzeba sobie uświadomić, że przez chrześcijańskie powołanie wszyscy stają się kimś jednym w Chrystusie. Kościół w tym samym momencie, kiedy dodaje człowiekowi sił do prawdziwie ludzkiego życia, włącza go poprzez chrzest do

\footnotetext{
${ }^{18}$ DI 1.

${ }^{19}$ Por. RM 5.

${ }^{20}$ Por VD 92-97.

${ }^{21}$ Por. DM 5.

${ }^{22}$ Por. RM 59.
} 
Kościoła jako dziecko Boże ${ }^{23}$. Chrześcijaństwo wyciska więc na swych wyznawcach piętno jedności z Chrystusem. Owo zjednoczenie dokonuje się poprzez sakramenty święte, przede wszystkim przez sakrament chrztu, bierzmowania i Eucharystii ${ }^{24}$. Są one początkiem misyjnej drogi każdego chrześcijanina. Każdy uczeń Chrystusa mniej lub bardziej świadomie zostaje więc włączony w ewangelizacyjne dzieło Kościoła poprzez sakramenty ${ }^{25}$. W tej perspektywie wszyscy wyznawcy Chrystusa, gdziekolwiek się znajdują, są zobowiązani tak ukazywać świadectwem słowa i przykładem życia nowego człowieka, przyobleczonego przez chrzest i działanie Ducha Świętego, który umocnił ich w sakramencie bierzmowania, aby inni widząc ich dobre czyny, chwalili Ojca i pełniej pojęli prawdziwy sens życia ludzkiego i powszechną więź wspólnoty ludzkiej².

Sakramenty wtajemniczenia, którymi są chrzest, bierzmowanie i Eucharystia, są fundamentami całego życia chrześcijańskiego życia moralnego ${ }^{27}$. W punkcie wyjściowym życia chrześcijańskiego jest chrzest. Wprowadza on człowieka na drogę życia określoną według zamysłów Bożych, a jednocześnie obdarowuje tymi wszystkimi możliwościami działania, jakich prowadzenie takiego życia wymaga. Chrzest jest bramą życia w Duchu i bramą otwierającą dostęp do innych sakramentów. Poprzez chrzest człowiek zostaje wyzwolony z od grzechu, wszczepiony w Kościół i staje się uczestnikiem jego posłania ${ }^{28}$. Św. Paweł wielokrotnie w swych listach odwołuje się do chrztu, jako tajemnicy ścisłego zjednoczenia z Chrystusem. Zjednoczenie to wynika z miłosierdzia Bożego, jest odnawiającym i odradzającym obmyciem. Jest to również przyobleczenie się w Chrystusa i udział w Jego śmierci i zmartwychwstaniu (por. Tt 3, 5; Ga 3, 27; Rz 6, 3-11).

Przyjęcie chrztu świętego jest nawiązaniem z Chrystusem specjalnej więzi. Daje to człowiekowi zdolność i siłę do życia według Chrystusa. On sam chcąc być wciąż z nami oddaje się nam. Staje się towarzyszem i przewodnikiem w drodze do Ojca. Duch Święty, którego Jezus udziela nam na tej trudnej drodze chrześcijańskiego życia, staje się nam mocą i światłem. Obdarza ochrzczonego zaczątkiem swoich Darów. Są one

${ }^{23}$ Por. J. M. Goiburu Lopetegui, Duch misyjny. Vademecum, Warszawa 1991, s. 28.

${ }^{24}$ Por. A. Kmiecik, Posytam Was. Misja Chrystusa Odkupiciela powierzona Kościołowi, Warszawa 1995, s. 92.

${ }^{25}$ Por. VD 53.

${ }^{26}$ Por. DM 11.

${ }^{27}$ Por. Katechizm Kościoła Katolickiego, Poznań 1994, nr 1212 (dalej: KKK).

${ }^{28}$ Por. tamże, nr 1213. 
koniecznym wyposażeniem w drodze do Ojca. Pełnia owych Darów zostanie wylana na ochrzczonych dopiero przy bierzmowaniu. Jednak już te otrzymane przy chrzcie są inicjacją dla Ducha Świętego do podjęcia kierownictwa w życiu chrześcijańskim człowieka. Chrzest będąc zaczątkiem życia Bożego w człowieku, daje również początek dialogu miłości człowieka z Bogiem ${ }^{29}$.

W Ewangelii dowiadujemy się, że Jan Chrzciciel posługuje się znakiem obmycia wodą. Jest to znak oczyszczenia duszy przez pokutę. Zapowiada również chrzest, który miał być ustanowiony przez Tego, którego Jan poprzedza: „Ja was chrzczę wodą dla nawrócenia; lecz Ten, który idzie za mną, mocniejszy jest ode mnie; ja nie jestem godzien nosić Mu sandałów. On was chrzcić będzie Duchem Świętym i ogniem" (Mt 3, 11). Sam Jezus w nocnej rozmowie z Nikodemem mówi o konieczności odrodzenia, wiążąc je z wodą jako znakiem: "Jeśli się ktoś nie narodzi z wody i z Ducha, nie może wejść do królestwa Bożego" (J 3, 5). Jezus najprawdopodobniej sam nie posługiwał się znakiem odrodzenia $z$ wody. Ale przed swoim wniebowstąpieniem poleca Apostołom głosić dobrą nowinę zbawienia i udzielać chrztu: „Idźcie więc i nauczajcie wszystkie narody, udzielając im chrztu w imię Ojca i Syna i Ducha Świętego" (Mt 28, 19; por. Mk 16, 16). Kierując do Apostołów nakaz misyjny przed wniebowstąpieniem, Chrystus obok głoszenia Ewangelii nakazuje również udzielać wszystkim chrztu. Są w nim także wyrażone konsekwencje przyjęcia tego obrzędu przez tych, do których dotrze słowo Boże: „Kto uwierzy i przyjmie chrzest, będzie zbawiony; a kto nie uwierzy, będzie potępiony" (Mk 16, 16). Słowa Chrystusa, stanowiące według świadectwa Ewangelii Mateusza i Ewangelii Marka ostatnie Jego polecenie przed wniebowstąpieniem, Kościół rozumiał zawsze w ten sposób, że chrzest jest konieczny do zbawienia i że ci, którzy wystarczająco poznali Ewangelię, powinni przyjać ten sakrament. Chrzest stanowi bramę zbawienia, jest źródłem łaski nadprzyrodzonej i niezastąpionym darem miłosierdzia Bożego względem człowieka ${ }^{30}$.

Chrzest, oczyszczając z grzechu pierworodnego, jest pierwszym nawróceniem i odrodzeniem dla grzesznego człowieka. Nie sprzeciwia się on wolności człowieka i nie odcina go radykalnie i jednorazowo od grze-

${ }^{29}$ Por. S. Olejnik, Teologia moralna życia osobistego, Włocławek 1999, s. 28.

${ }^{30}$ Por. J. Nagórny, Chrzest - nowe życie w moralności Nowego Przymierza, w: Chrzest - nowość życia. Homo meditans X, red. A. J. Nowak, W. Słomka, Lublin 1992, s. $123-137$. 
chu. Jest jednak obietnicą i ciągłym Bożym wezwaniem do podnoszenia się z upadku i odchodzenia od grzechu. Ważnym czynnikiem zawartym $\mathrm{w}$ trwałym zobowiązaniu wnoszonym przez pierwszy sakrament inicjacji chrześcijańskiej jest przestroga przez odejściem od Chrystusa, przed odstępstwem od Niego. Ta perspektywa, niestety, ciągle istnieje dla człowieka ochrzczonego. Nie jest on wolny od możliwości, a nawet od pewnej skłonności do zejścia $\mathrm{z}$ drogi zbawienia, do popadnięcia $\mathrm{w}$ dawne błędy. Ale nie ginie też $\mathrm{w}$ nim wewnętrzne wezwanie płynące $\mathrm{z}$ faktu chrztu, z jego "charakteru sakramentalnego", by trwać w łączności z Chrystusem i dochować Mu wierności w życiu ${ }^{31}$.

Wezwanie do świętości, które niesie ze sobą chrzest, zostaje potwierdzone i wzmocnione w sakramencie bierzmowania. „Kiedy Apostołowie w Jerozolimie dowiedzieli się, że Samaria przyjęła słowo Boże, wysłali do niej Piotra i Jana, którzy przyszli i modlili się za nich, aby mogli otrzymać Ducha Świętego. Bo na żadnego z nich jeszcze nie zstąpił. Byli jedynie ochrzczeni w imię Pana Jezusa. Wtedy więc kładli Apostołowie na nich ręce, a oni otrzymywali Ducha Świętego" (Dz 8, 14-17). Owo „wkładanie rąk" oznacza bierzmowanie ${ }^{32}$.

Odnajdujemy w bierzmowaniu, podobnie jak i w chrzcie wezwanie Boże do pracy misyjnej: dzięki bierzmowaniu zachodzi uświęcające spotkanie z Chrystusem zsyłającym na wiernych Ducha Uświęciciela. Znajdujemy $\mathrm{w}$ nim nie tylko obdarowanie, ale także zaproszenie i wezwanie do ściślejszego współdziałania z Chrystusem i Duchem Świętym nad zdobywaniem świętości - stanu pełnego poddania się działaniu w nas i przez nas Ducha Świętego. Trzeba pójść za wezwaniem Chrystusa i poddać się uświęcającej mocy Jego Ducha Uświęciciela, zmierzając konsekwentnie i wytrwale do możliwie doskonałego pełnienia woli Ojca Niebieskiego. Bierzmowanie jest więc sakramentem, który daje Ducha Świętego, byśmy jeszcze głębiej utwierdzili się w Bożym synostwie, ściślej wszczepili się w Chrystusa. Bierzmowanie umacnia więź z Kościołem i włącza nas bardziej w jego posłannictwo i misję świadczenia o wierze chrześcijańskiej33.

Pierwsze zesłanie Ducha Świętego w Wieczerniku dokonało się w blasku ognia i przy szumie wichru, co podkreśliło dynamiczny charak-

${ }^{31}$ Por. S. Olejnik, dz. cyt., s. 32.

${ }^{32}$ Por. F. J. Ripley, This is the faith, Liverpool 1973, s. 182. Por. także: A. F. Dziuba, Sakrament bierzmowania w dynamice wiary, „Studia Pelplińskie” 16 (1985), s. 274.

${ }^{33}$ Por. KKK 1316. 
ter tego wydarzenia. Do niego też odnosi nas zsyłanie przez Chrystusa tegoż Ducha na wiernych w sakramencie bierzmowania. Jest to sakrament, który łączy nas ściśle z Duchem mocy i aktywności, Tym, który przekonuje świat „o grzechu, sprawiedliwości i o sądzie” (J 16, 8). Przynosząc Ducha mocy i wielkości, powołuje i wzywa do właściwego odzewu. Zobowiązuje do tego, by budzić w sobie udzieloną moc, odpowiedzieć wezwaniu do wielkości, na miarę udzielonych darów. Chodzi o zajęcie postawy chrześcijańskiego męstwa, tzn. przezwyciężenia trudności i niebezpieczeństw w dążeniu do realizacji dobra, jak też i o wielkoduszność, czyli o stawianie sobie stosunkowo wielkich zamierzeń i o konsekwentne zmierzanie do ich realizacji ${ }^{34}$.

Włączając się, poprzez bierzmowanie, jeszcze mocniej w życie Kościoła, należałoby zaangażować się w nie na tyle, by „współodczuwać” z Kościołem. Szczególnym wyrazem tej jedności jest cierpienie wraz z nim, kiedy spotykają go klęski czy niepowodzenia. Współodczuwaniem z Kościołem jest więc bycie z Kościołem ubogim i poniżonym, cierpiącym, słabym i upadającym, ale żyjącym w zjednoczeniu z Chrystusem zmartwychwstałym. Przejawy aktywnego uczestniczenia w życiu wspólnoty kościelnej można oddać przy pomocy wyrażenia wziętego z Ewangelii, a odnoszącego się do Kościoła. Jest on więc "domem Bożym”; buduje go Chrystus, ale przy współdziałaniu samych wiernych. Powinni oni wszyscy dołożyć swe cegiełki i czynnie współpracować w budowie ${ }^{35}$.

Bierzmowanie, będąc sakramentem dojrzałości chrześcijańskiej, pozwala, a także wymaga, by wziąć własny los w swoje ręce. Jest to wyzwanie, by całkowicie otworzyć się na Boga i ludzi, a także działać wyłącznie dla dobra innych. Wyrażona w ten sposób misyjność Kościoła, domaga się odpowiedzialności, dojrzałości i gotowości do głoszenia Ewangelii. Sakrament bierzmowania dysponuje jednak w sposób szczególny do dynamicznego działania bezpośrednio w płaszczyźnie zbawczej. Dając większy udział w zbawczej misji Chrystusa i w Jego potrójnej funkcji, nie tylko czyni bierzmowanych sposobnymi, ale i zobowiązuje do realizowania tego udziału, do aktualizowania swego ontycznego wyposażenia. Na mocy sakramentu ci, który przyjmują bierzmowanie, mają się stać czynnymi i mężnymi wyznawcami Jezusa Chrystusa. Powinni więc

${ }^{34}$ Por. S. Olejnik, dz. cyt., s. 42.

${ }^{35}$ Por. Cz. Bartnik, Bierzmowanie Kościoła, "Collectanea Theologica” 48 (1978), s. 27-30; M. Kowalczyk, Eklezjalno-apostolski charakter bierzmowania, "Communio" 12 (1992) nr 2, s. 93-99. 
włączyć się w dzieło ewangelizacji, dawać słowem i życiem świadectwo prawdzie Chrystusowej, wyznawać swą wiarę z odwagą i ofiarnie ${ }^{36}$. Już chrzest inicjuje to powołanie i wnosi takie zadanie do spełnienia. Bierzmowanie potwierdza je i potęguje. Obdarzeni tym sakramentem są nie tylko powołani do obrony wiary słowem i czynem, ale i do pełnego zaangażowania się w aktywność apostolską, do wyznawania i głoszenia wiary. Umocnieni darem Ducha Świętego mają dawać światu świadectwo o Chrystusie, powinni przemieniać ten świat według nauki i zbawiać go mocą Chrystusa ${ }^{37}$.

Najświętsza Eucharystia dopełnia wtajemniczenie chrześcijańskie. Ci, którzy przez chrzest zostali wyniesieni do godności królewskiego kapłaństwa, a przez bierzmowanie zostali głębiej upodobnieni do Chrystusa, za pośrednictwem Eucharystii uczestniczą razem z całą wspólnotą w ofierze Pana ${ }^{38}$. Należy pamiętać, że „Kościół żyje dzięki Eucharystii. Ta prawda wyraża nie tylko codzienne doświadczenie wiary, ale zawiera w sobie istotę tajemnicy Kościoła. Dzięki Najświętszej Eucharystii, w której następuje przeistoczenie chleba i wina w Ciało i Krew Pana, raduje się tą obecnością w sposób szczególny. Od dnia Zesłania Ducha Świętego, w którym Kościół, Lud Nowego Przymierza, rozpoczął swoje pielgrzymowanie ku ojczyźnie niebieskiej, Najświętszy Sakrament niejako wyznacza rytm jego dni, wypełniając je ufną nadzieją" ${ }^{\prime 39}$. Podczas Ostatniej Wieczerzy bowiem Chrystus ustanowił Eucharystyczną Ofiarę Ciała i Krwi, aby na wieki, aż do swego przyjścia, utrwalić Ofiarę Krzyża i Kościołowi powierzyć pamiątkę swej Męki i Zmartwychwstania: sakrament miłosierdzia, znak jedności, miłości, ucztę paschalną, w której dusza napełnia się łaską i otrzymuje zadatek przyszłej chwały ${ }^{40}$. „W Najświętszej Eucharystii zawiera się bowiem całe dobro duchowe Kościoła, to znaczy sam Chrystus, nasza Pascha i Chleb żywy, który przez swoje ożywione przez Ducha Świętego i ożywiające Ciało daje życie ludziom" ${ }^{\prime 4}$.

Eucharystia, pojęta jako zbawcza obecność Jezusa we wspólnocie wiernych i jako jej pokarm duchowy, jest czymś najcenniejszym, co

${ }^{36}$ Por. DM 11, 36.

${ }^{37}$ Por. Jan Paweł II, Encyklika "Dominum et Vivificantem", Watykan 1986, nr 54.

${ }^{38}$ Por. KKK 1322.

${ }^{39}$ Jan Paweł II, Encyklika "Ecclesia de Eucharistia”, Watykan 2003, nr 1 (dalej: EE).

${ }^{40}$ Por. Sobór Watykański II, Konstytucja o liturgii świętej "Sacrosanctum concilium", w: Sobór Watykański II, Konstytucje..., nr 47.

${ }^{41}$ Sobór Watykański II, Dekret o postudze i życiu kaptanów "Presbyterorum ordinis", w: Sobór Watykański II, Konstytucje..., nr 5 (dalej: DK). 
Kościół posiada na drogach historii ${ }^{42}$. Jednocząc wiernych przy eucharystycznym stole, daje im zarazem siłę do prawdziwie chrześcijańskiego życia moralnego ${ }^{43}$. Wierni uczestnicząc w Ofierze eucharystycznej, źródle i szczycie życia chrześcijańskiego, składają Bogu samych siebie. Posileni w Komunii świętej Ciałem Chrystusowym, przedstawiają jedność Ludu Bożego ${ }^{44}$. „Sobór Watykański II przypomniał , że Ofiara eucharystyczna tkwi w centrum procesu wzrastania Kościoła. Stwierdziwszy bowiem, że «Kościół, czyli królestwo Chrystusa już teraz obecne w misterium, z mocy Boga rośnie w sposób widzialny w świecie», i chcąc niejako odpowiedzieć na pytanie: «W jaki sposób wzrasta?», dodaje: «llekroć sprawowana jest na ołtarzu ofiara krzyża, w której „Chrystus został złożony w ofierze jako nasza Pascha” (1 Kor 5, 7), dokonuje się dzieło naszego Odkupienia. Jednocześnie w sakramencie Chleba eucharystycznego przedstawiana jest i dokonuje się jedność wiernych, którzy stanowią jedno ciało w Chrystusie (por. 1 Kor 10, 17)»"45.

Włączenie w Chrystusa, dokonujące się w Chrzcie św., odnawia się i umacnia przez udział w Eucharystii, gdy jest uczestnictwem pełnym przez udział w Komunii. W Komunii eucharystycznej realizuje się wspólna, wewnętrzna więź Chrystusa i ucznia. Jednocząc się z Chrystusem, Lud Nowego Przymierza daleki jest od zamykania się w sobie, staje się «sakramentem» dla całego rodzaju ludzkiego, znakiem i narzędziem zbawienia dokonanego przez Chrystusa, światłem świata i solą ziemi (por. Mt 5, 13-16) dla odkupienia wszystkich ${ }^{46}$.

W tej perspektywie słuszne wydają się słowa papieża Benedykta XVI zawarte w posynodalnej adhortacji apostolskiej Sacramentum caritatis mówiące o tym, że "nie możemy przystępować do stołu eucharystycznego bez włączenia się $\mathrm{w}$ dynamikę misji, która bierze początek w samym Sercu Boga i zmierza do tego, by objąć wszystkich ludzi. Dlatego częścią

${ }^{42}$ Por. EE 9.

${ }^{43}$ Papież Benedykt XVI odwołując się do swojego poprzednika na Stolicy Piotrowej tak mówi o związku pomiędzy Eucharystia a życiem moralnym chrześcijanina: „Papież Jan Paweł II potwierdził, iż życie moralne 'ma walor rozumnej służby Bożej (Rz 12, 1; por. Flp 3, 3), która wypływa i bierze moc z tego niewyczerpanego źródła świętości i uwielbienia, jakim są sakramenty, zwłaszcza Eucharystia'”. Benedykt XVI, Posynodalna adhortacja apostolska Sacramentum caritatis, Rzym 2007, nr 82 (dalej: SC).

${ }^{44}$ Por. Sobór Watykański II, Konstytucja dogmatyczna o Kościele „Lumen gentium”, w: Sobór Watykański II, Konstytucje..., nr 11 (dalej: KK).

${ }^{45}$ EE 21.

${ }^{46}$ Por. Benedykt XVI, Encyklika "Deus caritas est", Rzym 2005, nr 13-14. 
konstytutywną eucharystycznej formy egzystencji chrześcijańskiej jest duch misyjny" ${ }^{\prime \prime 7}$. Z tego wynika, że Eucharystia nie tylko jest źródłem i szczytem życia Kościoła, ale również jego misji. Kościół autentycznie eucharystyczny jest Kościołem misyjnym. „Dlatego - uczy dalej papież Benedykt XVI - tajemnica eucharystyczna, w którą się wierzy i którą się celebruj, domaga się ciągłego wychowywania wszystkich do pracy misyjnej, której ośrodkiem jest głoszenie Jezusa, jedynego Zbawiciela"48.

Z pewnością głos Pana rozbrzmiewa w głębi duszy każdego chrześcijanina, który przez wiarę i sakramenty chrześcijańskiej inicjacji upodobnił się do Jezusa Chrystusa, stał się żywym członkiem Kościoła i aktywnym podmiotem jego zbawczej misji ${ }^{49}$.

\section{INKULTURACJA I DIALOG MIĘDZYRELIGIJNY FUNDAMENTALNYM WYZWANIEM MORALNYM DLA MISYJNEJ DZIAŁALNOŚCI KOŚClOŁA}

Pan Jezus, dając misyjny nakaz, rozesłał Apostołów do wszystkich ludzi, wszystkich narodów i do wszystkich miejsc na ziemi. W Apostołach Kościół otrzymał misję powszechną, która nie ma granic i dotyczy zbawienia $\mathrm{w}$ całej jego integralności. Ta różnorodność ludzi, miejsc, kultur, jaka jest zapisana $\mathrm{w}$ naturze misji, jest ogromnym i niełatwym wyzwaniem dla misjonarzy. „Prowadząc działalność misyjną wśród narodów, Kościół spotyka różne kultury i zostaje wciągnięty w proces inkulturacji. Jest to potrzeba, która zaznaczyła się $\mathrm{w}$ całej jego drodze dziejowej, ale dziś jest szczególnie żywa i paląca"50.

Jan Paweł II w książce Przekroczyć próg nadziei, mówiąc o ewangelizacji, przytoczył postać apostoła Pawła. „Spotkanie Ewangelii ze światem hellenistycznym okazało się nad wyraz owocne. Wśród wszystkich słuchaczy, jakich Paweł zdołał zgromadzić wokół siebie, na szczególną uwagę zasługują ci, którzy przyszli go słuchać na ateńskim Areopagu. Trzeba, aby tutaj przeanalizować przemówienie św. Pawła na Areopagu, które jest swego rodzaju arcydziełem. To, co Apostoł mówi i jak to mówi, ujawnia cały jego geniusz ewangelizacyjny. Wiemy, że w tamtym dniu

\footnotetext{
47 SC 103.

48 Tamże, nr 86.

49 Por. Jan Paweł II, Adhortacja apostolska „Christifideles laici”, Watykan 1988, nr 3.

50 Tamże, nr 52.
} 
kazanie zakończyło się niepowodzeniem. Jak długo Paweł mówił o Bogu nieznanym, słuchacze czuli $\mathrm{w}$ jego słowach coś, co odpowiadało ich własnej religijności. Kiedy natomiast wspomniał o zmartwychwstaniu, natychmiast zareagowali sprzeciwem. Paweł musiał wyczuć, że tajemnica zbawienia $\mathrm{w}$ Chrystusie $\mathrm{z}$ trudem będzie się musiała przebijać poprzez przyzwyczajone do mitologii, a równocześnie do wielorakich spekulacji filozoficznych, umysły Helleńczyków" ${ }^{\prime 51}$. Analiza, jaką przeprowadza w tym fragmencie papież, jest podłożem, do dalszych refleksji na temat inkulturacji.

Idea inkulturacji realizowana była bowiem przez całe dzieje Kościoła w sposób oczywisty i naturalny. Chrześcijaństwo zakorzeniało się w kulturach ewangelizowanych narodów, a zarazem czerpało z bogactwa tych kultur, przejmując niektóre elementy, które były zgodne z Ewangelią. Jak pisał Jan Paweł II „każdy człowiek, każdy naród, każda kultura i cywilizacja mają swoją rolę do wypełnienia i swoje miejsce $w$ tajemniczym planie Boga i w powszechnej historii zbawienia"52. To przystosowanie, jakim jest inkulturacja, dokonywało się zawsze, od początków istnienia Kościoła. Wielość, która tkwi już w stwórczym planie Boga, musi być uwzględniana również w działalności misyjnej ${ }^{53}$.

Jan Paweł II, zagłębiając się w tak ważny temat, jakim jest inkulturacja, w swoich kolejnych dokumentach stopniowo dochodzi do pełnej formy tego terminu. W adhortacji Catechesi tradendae z 1979 r. papież pisał: „Chcę stwierdzić, że katecheza, jak i ewangelizacja w ogóle, ma za zadanie wszczepienie siły Ewangelii $\mathrm{w}$ samą istotę jej kultury i ich zasadnicze elementy; dostrzegać to, co je jaśniej wyraża; szanować ich wartości i bogactwa. W ten sposób będzie mogła doprowadzić ludzi o różnych formach kultury do poznania ukrytej tajemnicy i dopomóc im $\mathrm{w}$ wydobywaniu $\mathrm{z}$ ich własnej żywej tradycji oryginalnych znaczeń chrześcijańskiego życia, sprawowania liturgii i sposobu myślenia" ${ }^{\prime 54}$.

Następnie w encyklice Slavorum Apostoli papież po raz pierwszy użył terminu „inkulturacja”. Określił go, jako wcielenie Ewangelii w rodzime kultury oraz wprowadzenie tych kultur w życie Kościoła ${ }^{55}$. W kolejnej encyklice papieskiej Redemptoris missio znajdujemy już pełną

\footnotetext{
${ }^{51}$ Jan Paweł II, Przekroczyć próg nadziei, Lublin 1994, s. 92.

52 Jan Paweł II, Encyklika „Slavorum Apostoli”, Watykan 1985, nr 19 (dalej: AS).

${ }^{53}$ Por. K. Müller, Teologia misji. Wprowadzenie, Warszawa 1989, s. 101.

${ }^{54}$ Jan Paweł II, Adhortacja apostolska "Catechesi tradendae", Watykan 1979, nr 53.

${ }^{55}$ Por. AS 21.
} 
definicję inkulturacji: „Inkulturacja oznacza wewnętrzne przekształcenie autentycznych wartości kulturowych przez ich integrację w chrześcijaństwie i zakorzenienie chrześcijaństwa w różnych kulturach" ${ }^{\prime 56}$. Wpatrując się $\mathrm{w}$ tajemnicę wcielenia i odkupienia, należy rozeznać wartości i antywartości kultur. W procesie inkulturacji Słowo Boże wchłania wartości autentyczne, oczyszczając je z grzechu ${ }^{57}$.

Na temat inkulturacji mówił też papież Benedykt XVI we wspominanej adhortacji Verbum Domini: „Inkulturacji nie należy mylić z powierzchownym przystosowaniem ani też z synkretycznym zamieszaniem, rozmywającym oryginalny charakter Ewangelii, aby uczynić ją łatwiejsza do przyjęcia. Autentycznym wzorem inkulturacji jest samo wcielenie Słowa: «Akulturacja lub inkulturacja, [...] będzie prawdziwym obliczem Wcielenia Słowa, zwłaszcza gdy kultura, przekształcona i odrodzona przez Ewangelię, wyda z własnej żywej tradycji oryginalny wyraz życia chrześcijańskiego»"58.

Z wypowiedzi papieskich wynika jednoznacznie, że inkulturacja jest obecnością realizującą się $\mathrm{w}$ procesie dialogu. Wspólnota chrześcijańska przyjmując wartości ludzi miejscowych, rozwija je w prawdziwie chrześcijańskim sensie i wprowadza do uniwersalnej komunii. ${ }^{59}$ Dekret misyjny stwierdza, że tradycje partykularne wraz z cechami właściwymi poszczególnych ludów, przepojone światłem Ewangelii, zostaną przyjęte do wspólnoty, zaś nowe Kościoły wzbogacone tradycjami kulturowymi znajdą swe miejsce w jedności Kościoła ${ }^{60}$. Przez inkulturację Kościół staje się bardziej zrozumiałym znakiem tego, czym jest i co wyraża. Kościół powszechny przez inkulturację Kościołów lokalnych wzbogaca się o formy wyrazu i wartości w różnych dziedzinach życia chrześcijańskiego, takich jak ewangelizacja, kult, teologia, dzieła miłosierdzia; poznaje i wyraża jeszcze lepiej tajemnicę Chrystusa, a jednocześnie jest pobudzany do stałej odnowy ${ }^{61}$.

Inkulturacja jest procesem długim, trudnym i bardzo delikatnym. Nie można bowiem naruszyć specyfiki i integralności wiary chrześcijańskiej. Nie można też zniszczyć dorobku kulturowego narodów. „Ewan-

${ }^{56}$ RM 52.

${ }^{57}$ Por. Jan Paweł II, Adhortacja apostolska "Ecclesia in Africa", Watykan 1995, nr 61 (dalej: EA ).

${ }^{58}$ VD 115.

${ }^{59}$ Por. A. A. Roest Crollius, Inkulturacja, w: Kościót misyjny..., s. 126.

${ }^{60}$ Por. DM 22.

${ }^{61}$ Por. RM 52. Por. także: SC 54. 
gelia nie prowadzi do zubożenia czy zgaszenia tego, co każdy człowiek, lud i naród, każda kultura w ciągu historii poznają i realizują jako dobro, prawdę i piękno. Zachęca raczej, by te wartości zostały zasymilowane i rozwijane: by wielkodusznie i z radością były wprowadzane w życie i uzupełniane tajemniczym i wywyższającym światłem Objawienia"62. Wspólnoty kościelne dopiero rozwijające się, poprzez natchnienie Ewangelii, mogą wyrażać własne doświadczenie chrześcijańskie znanymi i bliskimi sobie formami, tożsamymi z kulturą, jednak zawsze zgodnie z wymogiem wiary ${ }^{63}$.

W pojęciu inkulturacji wyodrębnić można dwa elementy: wcielenie Ewangelii w różne kultury oraz wprowadzenie narodów z ich kulturami do wspólnoty Kościoła. Dwutorowość procesu inkulturacji ukazuje z jednej strony chrześcijańskie życie i orędzie przekazywane przez Kościół, a z drugiej wielość i różnorodność zmieniających się ciągle kultur ${ }^{64}$. Potrzeba więc u misjonarzy, ale również u wszystkich wiernych, wielkiej wyrozumiałości i otwartości. Potrzeba również pokory, gdyż to nie tylko chrześcijaństwo przyjmuje pod swe skrzydła, ale także jest przyjmowane. Z przybyciem bowiem misjonarzy dalekie ludy stają się niejako bliskie, a wspólnoty od dawna chrześcijańskie mają doskonałą sposobność do dia$\log$ z z narodami, które jeszcze nie słyszały Ewangelii oraz do pokazania im poprzez służbę miłości i pomocy prawdziwego oblicza Chrystusa ${ }^{65}$.

W tej perspektywie warto opisać sylwetkę misjonarza, który rozpoczynając ewangelizację, powinien posiadać pewne konkretne cechy potrzebne do pracy. Misjonarze pochodzący z innych Kościołów i krajów winni włączyć się w świat społeczno-kulturowy tych, do których zostali posłani, przezwyciężając uwarunkowania środowiska swojego pochodzenia. Tak więc winni nauczyć się języka regionu, w którym pracują poznać najbardziej znamienne przejawy tamtejszej kultury, odkrywając jej wartości w bezpośrednim doświadczeniu. Jedynie z taką wiedzą mogą oni nieść tym ludom w sposób wiarygodny i owocny poznanie ukrytej tajemnicy. W ich przypadku nie chodzi oczywiście o zaparcie się

${ }^{62}$ AS 18.

63 Por. RM 53.

${ }^{64}$ Por. A. A. Roest Crollius, Inkulturacja, w: Kościót misyjny..., s. 127.

65 Por. DM 38. „Obecność Jezusa Chrystusa oraz wylanie Ducha Świętego są wydarzeniami, które mogą w sposób trwały konfrontować się z każdą rzeczywistością kulturalną, aby ja poddać działaniu ewangelicznego zaczynu. W konsekwencji prowadzi to do zobowiązania, aby z przekonaniem podejmować ewangelizację kultur, w świadomości, że sam Chrystus jest prawda każdego człowieka oraz całej ludzkiej historii" (SC 78). 
własnej tożsamości kulturowej, ale o zrozumienie, docenianie, popieranie i ewangelizowanie kultury środowiska, w którym działają, a zatem o to, by byli w stanie nawiązać z nim rzeczywisty kontakt, przyjmując styl życia będący znakiem ewangelicznego świadectwa i solidarności $\mathrm{z}$ tamtejszymi ludźmi ${ }^{66}$.

Broniąc zdolności rozumu ludzkiego do poznania Boga, Kościół wyraża swoją ufność w możliwość mówienia o Bogu wszystkim ludziom i z wszystkimi ludźmi. Przekonanie to stanowi podstawę jego dialogu nawiązują dialog z ludzkością z innymi religiami, z filozofią i nauką, a także z niewierzącymi i ateistami ${ }^{67}$. Pisze o tym papież Benedykt XVI: „Mając świadomość, że Bóg Ojciec, Syn i Duch Święty nawiązują dialog z ludzkością, Kościół uważa, że do głoszenia Słowa Bożego w sposób zasadniczy należą spotkanie i dialog ze wszystkimi ludźmi dobrej woli i dąży dziś do dialogu z osobami należącymi do różnych tradycji religijnych, unikając form synkretyzmu i relatywizmu" ${ }^{\prime \prime}$.

Dialog międzyreligijny jest częścią składową ewangelizacyjnej misji Kościoła. Nie może być pojmowany jako zjawisko obok misji, ale jako integralna część i sposób realizacji misjíi . Dialog rozumiany jako metoda i środek wzajemnego poznania i ubogacenia jest powiązany w szczególny sposób z misją ad gentes - do narodów $\mathrm{w}^{70}$. Podobnie jak Bóg ofiaruje ludziom zbawienie, podejmując z nimi nieustanny dialog, również Kościół powinien kontynuować swoją misję w duchu dialogu, poddając się działaniu Ducha Świętego, który jest głównym sprawcą misjii¹.

„Dialog należy uważać jakby za pewien sposób wypełniania obowiązku apostolskiego i jakby za narzędzie do jednoczenia umysłów"72. Aby dialog przyniósł duchowe owoce powinien posiadać odpowiednie cechy. A mianowicie ma najpierw odznaczać się jasnością, która zapewni zrozumienie przekazywanych myśli. Następną cechą jest łagodność, której Chrystus kazał się uczyć od siebie samego (por. Mt 11, 29). Siła przekonania dialogu wywodzi się bowiem stąd, że przekazuje prawdę, ukazuje cnoty, rozsiewa miłość. Jest spokojny i niczego nie narzuca. W dialogu potrzebne jest również zaufanie - do mocy własnych słów,

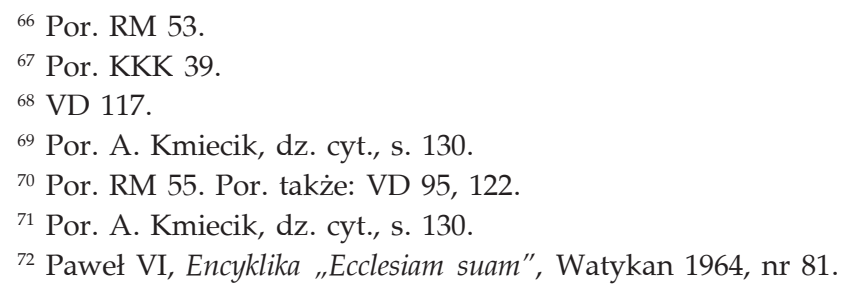


ale także do tego, że drugi człowiek będzie otwarty. Ostatnią cechą jest roztropność. To ona pozwala badać nastawienie słuchacza oraz jego możliwości i odczucia ${ }^{73}$. W takim spojrzeniu na „dialog” można również dostrzec sylwetkę misjonarza. Jest to poniekąd wskazanie na cechy, które winno się wypracowywać u przyszłych misjonarzy, by nie zaniedbać tak ważnej części misyjnego przygotowania, która niegdyś zaowocować może jednością Kościoła.

Dialog nie rodzi się w wyrachowania, ale posiada swoje głębsze uzasadnienie, jakim jest szacunek do dzieł Ducha Świętego. On bowiem ma swe tchnienie w każdym człowieku ${ }^{74}$. „Od pradawnych czasów aż do naszej epoki znajdujemy u różnych narodów jakieś rozpoznanie owej tajemniczej mocy, która obecnie jest w biegu spraw świata i wydarzeniach ludzkiego życia; nieraz nawet uznanie Najwyższego Bóstwa lub też Ojca. Rozpoznanie to i uznanie przenika ich życie głębokim zmysłem religijnym [...]. Kościół katolicki nic nie odrzuca z tego, co w religiach owych prawdziwe jest i święte. Ze szczerym szacunkiem odnosi się do owych sposobów działania i życia, do owych nakazów i doktryn, które chociaż w wielu wypadkach różnią się od zasad przez niego wyznawanych i głoszonych, nierzadko jednak odbijają promień owej Prawdy, która oświeca wszystkich ludzi. Głosi zaś i obowiązany jest głosić bez przerwy Chrystusa, który jest «drogą, prawdą i życiem» (J 14, 6), w którym ludzie znajdują pełnię życia religijnego i w którym Bóg wszystko z sobą pojednał. Przeto wzywa synów swoich, aby z roztropnością i miłością przez rozmowy i współpracę z wyznawcami innych religii, dając świadectwo wiary i życia chrześcijańskiego, uznawali, chronili i wspierali owe dobra duchowe i moralne, a także wartości społeczno-kulturalne, które u tamtych się znajdują"75. Inne religie pobudzają więc Kościół do działania, do odkrywania i rozpoznawania znaków obecności i działania Ducha ${ }^{76}$. W świetle ekonomii zbawienia Kościół nie widzi sprzeczności między głoszeniem Chrystusa a dialogiem międzyreligijnym, odczuwa jednak potrzebę godzenia ich w obrębie misji ad gentes. Trzeba bowiem, aby oba te elementy zachowywały swą ścisłą więź i zarazem swą odrębność, zatem nie należy ich mieszać ani nimi manipulować, ani uważać ich

${ }^{73}$ Por. tamże.

${ }^{74}$ Por. RM 56.

${ }^{75}$ Sobór Watykański II, Deklaracja o stosunku Kościoła do religii niechrześcijańskich „Nostra aetate”, w: Sobór Watykański II, Konstytucje..., nr 2.

76 Por. RM 56. 
za równoważne, tak jakby były zamienne. Kodeks Prawa Kanonicznego zaleca więc misjonarzom nawiązywanie dialogu z niewierzącymi poprzez świadectwo życia, by otwierać im drogę do Ewangelii w sposób jasny dla ich kultury i mentalności ${ }^{77}$.

Dialog jest jedną z dróg, które zapoczątkował sam Bóg. On sam też zatroszczy się o to, by dotrzeć do serc i umysłów ludzi. Nasza obecność w Kościele nadaje sens zabieganiom i trudom, jakie w próby dialogu wkłada wielu misjonarzy. Kościół jest bowiem znakiem i narzędziem jednoczenia ludzi z Bogiem i między sobą ${ }^{78}$. Idąc za słowami Soboru Watykańskiego II, zapisanymi w Dekrecie o ekumenizmie należy stwierdzić, że: „O odnowienie jedności troszczyć się ma cały Kościól, zarówno wierni jak i ich pasterze, każdy wedle własnych sił, czy to w codziennym życiu chrześcijańskim, czy też w badaniach teologicznych i historycznych. To staranie ujawnia już poniekąd istniejącą między chrześcijanami braterską łączność i prowadzi wedle Bożej łaskawości do pełnej i doskonałej jedności"79.

\section{ZAKOŃCZENIE}

Przeprowadzona refleksja nad misyjnym wymiarem życia moralnego chrześcijan ukazała, jak wielką rolę w Kościele odgrywa ewangelizacja. Misyjność Kościoła wypływa z jego natury. Głoszenie Bożego Słowa połączone ze świadectwem życia jest najważniejszym powołaniem chrześcijańskim. Obowiązek ewangelizacji jest przywilejem otrzymanym na chrzcie świętym, pogłębionym podczas bierzmowania, a odnawianym zawsze podczas Eucharystii. Są to te trzy momenty, kiedy Chrystus posyła do głoszenia Słowa Bożego. Ewangelizacja to służba dla bliźnich wypływająca $\mathrm{z}$ miłości, troska o ich przyszłe zbawienie. $\mathrm{Z}$ tego wynika, że życie moralne posiada istotnie wymiar misyjny. Bez odniesienia do korzeni, do misyjnej natury Kościoła, a więc misyjnej natury każdego chrześcijanina, byłoby pozbawione istotnego pierwiastka. Co więcej życie moralne posiada wymiar misyjny, ponieważ myśleć, mówić i pracować dla misji, to widzieć i kochać człowieka.

77 Por. Kodeks prawa kanonicznego, Poznań 1984, kan. 787.

${ }_{78}^{78}$ Por. A. Kmiecik, dz. cyt., s. 132.

${ }^{79}$ Sobór Watykański II, Dekret o ekumenizmie Unitatis redintegratio", w: Sobór Watykański II, Konstytucje..., nr 5. 
Dokonane studium, wskazuje na aktualność zagadnienia w odniesieniu do współczesnego Kościoła i każdego ucznia Chrystusa z osobna. Kwestia odnalezienia misyjnego wymiaru chrześcijańskiej moralności jest tematem ciągle niewyczerpanym i otwartym. Ponieważ całe chrześcijańskie życie moralne realizowane jest $\mathrm{w}$ dobie rosnących zmian na wielu płaszczyznach, zadaniem wiernych jest „poświęcić wszystkie siły nowej ewangelizacji, zwłaszcza $\mathrm{w}$ krajach, gdzie Ewangelia została zapomniana albo spotyka się $\mathrm{z}$ rozpowszechnioną obojętnością z powodu szerzącego się sekularyzmu" ${ }^{\prime 80}$. Oczywiście, aby praca ewangelizacyjna przynosiła owoce niezwykle ważna jest permanentna formacja moralna każdego chrześcijanina uwrażliwiająca go na sprawy misyjne Kościoła. Odpowiednia formacja powinna również przygotowywać na spotkanie i dialog z osobami różnych kultur i religii. Wzajemny szacunek i dialog pogłębi pokój i zgodę między narodami i przyczyni się do umocnienia poczucia powszechnego braterstwa.

\section{THE EVANGELIZING MISSION OF THE CHURCH AS A MORAL CHALLENGE ON THE EVE OF THE THIRD MILLENNIUM}

\section{SUMMARY}

The aim of the article is to show the missionary aspect of moral life with reference to the contemporary Church and each Christian individually. Moral life includes the missionary aspect because thinking, speaking and working for the missions mean seeing and loving each individual. What can be easily noticed when observing the constantly changing world is the topicality and the need of all Christians ' commitment to the missionary work of the Church. Evangelization is a vocation and a duty of all Christians. Thus, it is essential to see to it that making oneself a sincere gift to others could always be the first and the fundamental privilege of all Christians. What also seems to be very important so that the evangelizing work could bear fruit is a permanent moral formation of each Christian that would make one sensitive to the missionary work of the Church and prepare one for a meeting and a dialogue with people of different cultures and religions.

In spite of the fact that there are numerous publications or works which discuss this issue, the problem of finding the missionary aspect of Christian morality still remains an open and an inexhaustible topic. A large number and a variety of conciliar and papal documents makes it possible to present different aspects of a constant and an urgent need to evangelize the contemporary world. The evangelizing mission is a witness to faith, Christian maturity and formation. Moreover, it is also a witness to moral responsibility for those who do not know Jesus Christ yet.

80 VD 122. 